\title{
The new Basel Capital Accord: A major advance at a turbulent time
}

\author{
Chris Terry ${ }^{1}$
}

\begin{abstract}
In January 2008, the Australian Prudential Regulation Authority introduced the second-generation capital requirement, Basel II, that substantially extended the 1988 Capital Accord of the Basel Committee on Banking Supervision. This paper explains the main features of Basel II; reviews concerns about the likely effects of the new capital requirement; and assesses the new capital requirement in the context of the global financial crisis.
\end{abstract}

\section{Introduction}

In January 2008, the Australian Prudential Regulation Authority (APRA) adopted the new Capital Accord (Basel II) that had been developed by the Basel Committee on Banking Supervision (BCBS). ${ }^{2}$ Basel II is a much enhanced - meaning a more risk-sensitive and comprehensive - version of the capital requirement on banks, which is the principal regulatory tool of prudential supervision. The original Capital Accord (Basel I) had been adopted by the Reserve Bank of Australia (RBA) in 1988. It was meant to establish a minimum capital standard for internationally active banks. In Australia it has been applied to all authorised-depositing institutions (ADIs), except branches of foreign banks.

The development of the new Accord, which began in 1999, attracted considerable debate and criticism, and while its form and detailed provisions evolved in response to the debate, the introduced version (BCBS 2004b) has not met with universal approval. The main objectives of this paper are to explain the main features of the new Capital Accord as adopted by APRA and to assess criticism of the new capital requirement in the light of the global financial crisis (GFC) that was triggered by the US sub-prime loan crisis.

\footnotetext{
${ }^{1}$ School of Finance and Economics, University of Technology, Sydney, chris.terry@uts.edu.au. JEL Classification Numbers: G21, G28. This paper is based on work undertaken jointly with Peter Docherty. The author wishes to thank Peter Docherty and Warren Hogan for their many conversations on Basel II, the referees for their comments and, especially, William Coleman for his considerable constructive advice. Naturally, any errors are the author's responsibility.

2 The committee was established in 1974, and comprises the central bank governors (and prudential regulators where they are separate organisations) of the G10 countries: Belgium, Canada, France, Germany, Italy, Luxemburg, the Netherlands, Spain, Sweden, Switzerland, the United Kingdom and the United States. It is serviced by the secretariat of the Bank for International Settlements.
} 


\section{The origin of the Capital Adequacy Requirement}

The deregulation of financial systems during the 1970s and 1980s exposed their banks to a more competitive and riskier environment, that led to concerns about the stability of banks. These concerns motivated the establishment of the BCBS (in 1974) and its development of a new regime of prudential supervision that included a capital requirement. Capital provides a bank with a cushion to absorb losses and so provides it and the prudential regulator with an opportunity to resolve the risk the losses pose for the bank's depositors. Two years after it introduced its capital requirement (in 1986), the RBA modified the requirement in line with the BCBS's Capital Accord by basing the 8 per cent capital requirement on the risk-weighted value of a bank's assets rather than on the total value of its assets (see RBA 1988; 1989). The requirement is the ratio of a bank's capital (as defined) — the numerator — to its risk-adjusted assets as the denominator. This approach related (if crudely) the capital requirement to the risk-management aim of prudential supervision.

The risk-adjustment under the Capital Accord initially employed five rule of thumb credit-risk categories (subsequently reduced to four) into which a bank's assets were allocated. Low risk weights (zero and 20 per cent) were established for less-risky assets. Loans secured by residential mortgages were assigned a risk weight of 50 per cent, whereas all other loans were given a risk weight of 100 per cent. The denominator also included the credit-equivalent value of a bank's off-balance sheet exposures, such as its derivatives and standby credit facilities drawn down at the initiative of the bank's client, by including the resulting amounts in the respective asset risk categories according to the identity of the counterparty.

In July 1998 the RBA's responsibility for bank supervision and the state-based supervisory responsibilities for credit unions and building societies were transferred to APRA, which was established following a public enquiry into the functions of the financial system and its evolving nature. This organisation became the prudential supervisor of all ADIs in Australia (except branches of foreign-owned banks) and to which it continued to apply the requirements of the Basel Accord. Stability of Australia's financial system remained one of the responsibilities of the RBA. (RBA 2008b: 67-71)

\section{The Structure of Basel II}

The original Basel Accord's simplicity probably helped its introduction by national prudential regulators. But the insensitivity to variations in risk (both between and within risk categories) had the potential to increase the incentive for risk-taking behaviour. Hogan \& Sharpe (1997a and 1997b) and Gup (2003: 74 ), for example, argue that attaching a risk weight of $100 \%$ to all commercial loans irrespective of counterparty allowed banks to pursue higher-risk (to achieve 
higher return) lending since this requires no more capital than less-risky lending but has greater upside income potential. Basel II addressed this shortcoming by enabling the use of a much wider range of credit-risk weights, by providing for the use of different approaches to determining risk weights and by extending the capital requirement to cover all risks banks face.

Basel II has three pillars. The first deals with a bank's core capital requirement (Pillar 1); the second allows for supervisor discretion to adjust this requirement to allow for additional risk and particular circumstances (Pillar 2); and the third fosters market discipline (Pillar 3).

The main features of Basle II's pillars are introduced in turn.

\section{Pillar 1: Capital requirements for core risks}

Pillar 1 refines the calculation of regulatory capital in three important ways. First, it uses a more granular approach to credit-risk weights; second, it provides banks (subject to the regulator's approval) with a choice of methods for calculating risk weights for certain types of risk; and third, it incorporates operating risk into the capital requirement. The anatomy of Pillar 1 is represented in Figure 1, which shows the Basel II innovations in bold type to distinguish them from those of Basel I. Note the introduction of three possible approaches to the calculation of the capital requirement for credit risk under Basel II; the standardised (externally set) risk weights and two approaches that rely on internal ratings (the foundation internal ratings basis, FIRB, and the advanced internal ratings basis, AIRB). Observe the introduction of a capital requirement for operating risk also provides for three approaches to the calculation of the capital requirement. An introduction to each innovation follows.

The calculation of the capital requirement for credit risk starts by dividing a bank's assets into five categories (corporate, sovereign, bank, retail and equity) within which there are sub-groups reflecting the different risk parameters for each asset type. The capital requirement for each represents an attempt to capture the average probability that a loan to each category of borrower would default, and the proportion of the loan that would be lost if default occurred.

Under the standardised approach, risk-weights are prescribed for each risk category, where the risk of each is rated by the borrower's externally-determined credit-rating agency such as Standard and Poor's (S\&P). The value of the loans in each category is multiplied by the prescribed risk weight and the product is multiplied by 8 per cent to determine the minimum capital requirement. To illustrate, there are six credit-rating grades for corporate loans, where grade 1 covers loans rated AAA to AA- (on Standard and Poor's long-term scale), grade 2 covers $\mathrm{A}+$ to $\mathrm{A}-$ and so on. The standard risk weights vary from 20 per cent to 150 per cent for these grades (APRA, APS 112 and APG 112). While this is the 'default' approach, which can be viewed as an extension of Basel I, it 
represents a substantial advance. Basel I used just four risk weights, two of which (in Australia) covered the bulk of bank balance sheet assets. The standardised approach requires an improvement in risk-management systems to generate the data to satisfy Basel II's more granular risk categories. Most ADIs are using this approach, which is expected to generate, on average, a modest reduction in regulatory capital (Egan 2007).

\section{Figure 1: Capital requirement under Basel I and Basel II}

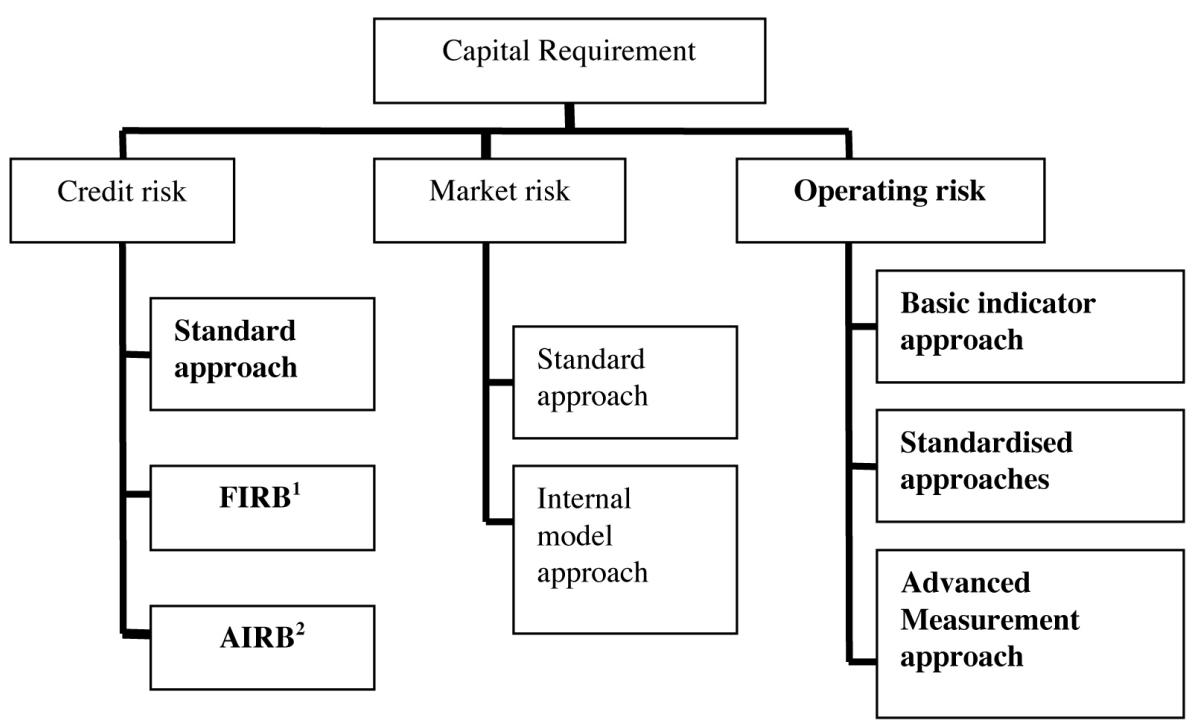

Notes: The new features (under Basel II) are shown in bold

${ }^{1}$ Foundation internal ratings based approach

${ }^{2}$ Advanced internal ratings based approach

Source: APRA 2004: 14.

The more radical innovation is the provision for banks to use either of two internal rating approaches subject to the regulator's (that is, APRA) approval. The foundation internal ratings-based approach (FIRB) uses internal estimates of the probability of loan defaults (PD) and feeds this into a more complex probability-based formula (that relies on the supervisor's estimates of the other risk components) to determine the risk weight to be used to calculate the amount of capital to be held against the loan. The advanced internal ratings-based approach (AIRB) uses internal estimates of loss given default (LGD) and the other risk components (effective maturity and the exposure at default) in a prescribed formula to determine the risk weight and hence the capital charge against a loan. These approaches derive from the internal risk assessments banks (including Australia's big banks) began undertaking in the 1990s and thus Basel II can be viewed as following industry practice. 
Basel II does not change the two methods that can be used for assessing the capital requirement for market risk introduced in 1996. However, it introduced a capital requirement for operational risk exposures. Operational risk refers to the risk that losses may result from a lack of verification and control processes (such as the loss of 4.9 billion at Société Généralé due to a trader's ability to circumvent operating systems that was revealed in January 2008). Three approaches for assessing operating risk are available; two that are relatively simple (the basic indicator and several standardised approaches) and the third advanced measurement approach (AMA) could be used by banks 'with advanced operational risk measuring and modelling capabilities'. Under the standardised approach, an ADI divides its activities into three categories - retail banking, commercial banking and all other activities, which have different capital requirements - and the sum of these requirements sets the ADI's operational risk-capital requirement. The capital requirement for retail and commercial banking is based on an ADI's gross outstanding loans and advances (as an indicator of its operating risk exposure) whereas for the third category the capital requirement is based on the ADI's gross income from these activities (APRA, APS114). To be accredited to use the advanced approach banks must have 'an operational risk management framework that is sufficiently robust to facilitate quantitative estimates of the ADI's ORRC (operational risk regulatory capital) that are sound, relevant and verifiable' in relation to the 'complexity of the ADI's business' (APRA, APS115: para. 21).

Three banks were accredited to use the advanced methods from January 2008 and a fourth (NAB) was given approval to use the foundation IRB approach. Three other banks have applied to move to an IRB approach during 2008 and are operating under Basel I in the meantime (RBA 2008a: 67). The advanced approaches are expected to reward banks with modest reductions in regulatory capital (for lower credit-risk exposures); although 10 per cent will be the maximum reduction in 2008 and 2009 (under Pillar 2 provisions) while the banks are demonstrating the performance of their risk-management models (Egan 2007).

\section{Pillar 2: The Supervisory Review Process}

Pillar 2 has two aspects. The first requires banks to assess their overall risk profile (in addition to the risks specified under Pillar 1) and to calculate any further capital that should be held against this additional risk. The additional risks potentially identified under Pillar 2 include credit concentration risk, liquidity risk, reputation and model risk. Consequently, Pillar 2 could be expected to add to the amount of capital held by banks (and offset the lower credit-risk capital requirement).

The second aspect of Pillar 2 is its inclusion of a 'supervisory review process'. This allows supervisors to evaluate each bank's overall risk profile and to mandate a higher prudential capital ratio where this is judged to be prudent (APRA, APS 
110). APRA's decision to increase $\mathrm{NAB}^{\prime}$ s capital requirement following its foreign exchange losses (in January 2004) illustrates this process.

\section{Pillar 3: Market Discipline}

Pillar 3 requires disclosure of information regarding the calculation of bank capital positions and risk-management processes designed to strengthen the capacity of security markets to respond to changes in bank risk profiles. The idea is that banks which the market judges to have increased their risk profiles without adequate capital will have their securities sold down in debt and equity markets. The additional costs that this will impose on financing bank operations will provide an incentive for management to modify either the bank's risk profile or its capital base. This dimension of Basel II is thus designed to complement Pillars 1 and 2 by providing additional discipline on bank risk-taking behaviour.

APRA's prudential information disclosure requirements are most detailed for the Australian-owned ADIs that use the advanced risk-management approaches because of their use of internally-generated risk ratings. They are required to report quantitative risk-management information on a semi-annual basis and qualitative risk-management information on an annual basis, as well as reporting basic capital-adequacy information on a quarterly basis. The reporting requirements are less detailed for the ADIs that use the standard risk weights and for overseas-owned ADIs, assuming their home regulator's prudential information disclosure requirements are equivalent to APRA's (APRA June 2007 and APS330).

\section{Securitisation}

In this and the next sub-section Basel II's approach to securitisation (BCBS 2004b: 120-43) and credit risk mitigation (BCBS 2004b: 31-51) within Pillar 1 are introduced because of the role these processes played in the crisis triggered by the US sub-prime loan debacle (which is discussed in section 5). The process of moving assets (these principally have been housing loans) off the balance sheet via securitisation (a variation of the 'originate-to-distribute' model used by Australia's loan originators) has been an important feature of bank asset-liability management. In Australia it has been used especially by the regional banks.

The assets are securitised through the services of a special-purpose vehicle (SPV) established by a bank. The SPV arranges the issue of asset-backed securities (mortgage-backed securities, MBSs, where housing loans are involved) to investors and pays the bank for the loans with the proceeds. The bank avoids a capital requirement for the securitised assets provided the arrangement ensures it is no longer exposed to any risks associated with the assets, such as the risks that would arise if the originating bank agreed to any explicit credit enhancement of the securities or from implicit liquidity or solvency support for the SPV which 
could result in the securitised assets being brought back onto the originator's balance sheet.

\section{Credit-risk mitigation}

An important dimension of Basel II is its treatment of credit-risk mitigation techniques such as the use of collateral, guarantees (by a third party) and other credit-risk reduction measures such as credit derivatives, which reduce the amount of loss in cases of default. Credit-default swaps (CDS) are the most extensively used credit derivative. They provide banks with the opportunity to buy protection against default events on one or more of its assets, which would reduce its credit risk. For example, a bank could purchase credit-risk protection on a specified set of loans or corporate securities held by the bank by issuing a CDS and paying a premium (this would be paid six monthly at the agreed rate) to the party that decides to accept the credit risk (such as a bond investment manager or another bank that wants to diversify its credit risks). The protection seller faces the obligation to compensate the protection buyer should pre-defined default events occur on the specified parcel of loans or securities. Should a default event occur the bank would receive a compensation payment and this lowers its loss given default, whereas should no default event occur the seller would receive the premium payments without having to compensate the bank.

Basel II explicitly recognises the role of banks' increasing use of instruments such as credit derivatives. Since these instruments reduce the risk of loss they reduce a bank's capital requirement. The reduction depends on the credit standing of the provider of the credit-risk mitigation instrument, such as the protection seller in the case of CDS. Thus the risk-weighted assets are adjusted using a risk weight appropriate to the risk class of the protection seller. For protection sold under the CDS, the same process is followed but the risk weight applied is that appropriate to the reference credit being protected.

\section{Concerns debated during the development of Basel II}

During the development of Basel II there was extensive debate internationally over the model's continued use of the 8 per cent capital ratio, the model's pro-cyclical effects, the effectiveness of market discipline and its impact on bank lending to small and medium-sized businesses. In Australia, concerns were expressed that Basel II would result in a lower capital requirement on the big banks than on the regional banks. These issues are considered below.

\section{The amount of required capital}

A primary concern was, and, is whether Basel II's capital requirement is adequate. In a structural sense this concern has two parts: should Basel II maintain the 8 per cent capital ratio and are the new risk weights in Pillar 1 (subject to any 
action under Pillar 2) adequate? The historical record in developed economies over the last 30 years is that 90 per cent of failed institutions reported capital ratios at or near the regulatory minimum just prior to failure (BCBS 2004a). This raises the question of the requirement's adequacy, if the purpose of the capital requirement is to prevent bank insolvencies.

Gup (2004a) argued that the amount of regulatory capital implied by Basel II is too low for banks in the United States. Gup reasoned that the operational profile of US banks (in 2004) was much more risky than it was in 1988 on account of three sources of their altered risk profile: increased exposure of US banks to commercial property loans; an increased proportion of bank portfolios dedicated to sub-prime lending; and greater exposure to derivatives markets. Gup's concerns about bank's sub-prime assets and credit derivatives were well founded and imply that the risk weights attached to these loans and contracts were inadequate.

On the other hand, Altman, Bharath \& Saunders (2002: 917-20) challenged the credit-risk weights for the standardised approach in an earlier version of the framework as well as the range of proposed risk categories for corporate loans. They found using the default experience of US corporate bonds over the period 1981-99 that the capital requirements on highly rated borrowers (A and BBB/BB classes) were significantly higher under the 2001 version of Basel II than is justified by the default experience of such high-grade bonds (that is, borrowers), while for more poorly rated borrowers (below $\mathrm{BB}$ ) the risk weight was about right. These findings held also for the 1989-92 recession; but clearly the findings are not representative of the recent experience with securities backed by US sub-prime housing loans or with similarly rated corporate bonds.

APRA estimated that Basel II's introduction may marginally reduce the Australian banking system's required amount of capital and has advised that it will take a cautious approach toward reductions in regulatory capital during the initial years under Basel II (Egan 2007).

Australia's 20-year experience with the Capital Accord suggests the amount of regulatory capital has been adequate. Over this period there had been a recession in the early 1990s (accompanied significantly by a collapse in the commercial property market) when substantial losses were incurred at two large Australian banks (Westpac and ANZ). The capital held by these banks absorbed these losses and allowed them time to restore their capital ratios (Gizycki \& Lowe 2000: 181-6). The results of the stress tests of the Australian financial system conducted by the IMF in early 2006 - that the banking system would cope (with reduced profits) under its macroeconomic shock scenarios - imply that the banking system was holding adequate capital in the tested scenarios (RBA 2006: 46). 
Moreover, Australia's banks have maintained capital ratios well above the regulatory minimum. As a group, the Australian-owned banks have maintained a capital ratio of between 10 and 12 per cent and credit unions and building societies have maintained higher ratios since the introduction of Basel I, and these capital ratios increased in 2008 (RBA 2008b: 26). Such ratios reflect each bank's judgement of the amount of capital it should use in its financing. These judgements would depend on each bank's calculations of its economic capital requirement. Economic capital is the amount of capital a bank holds to protect its solvency from unexpected losses (and from inadequate provisions against expected losses). Its purpose is to ensure the bank is able to continue operating (that is, remain solvent) should it incur unexpected losses. Since banks have liabilities in addition to their deposits, a bank's economic capital is likely to exceed the regulatory requirement.

The evidence as at the end of 2008 (putting aside the Government's recent guarantee of bank liabilities) supports the conclusion that the capital requirement under Basel II as applied by APRA has been adequate given the approach of Australia's ADIs toward risk taking and risk management and APRA's approach to prudential supervision.

\section{The Pro-cyclical Nature of the Basel II Capital Standard}

An important criticism of Basel II is its pro-cyclical effects on economic activity that could amplify and prolong macroeconomic fluctuations. A substantial literature has analysed the cyclical nature of probabilities of default, exposure at time of default and losses given default and the consequences of capital requirements that are adjusted for these cyclical risk factors (such as Resti 2002; Kashyap \& Stein 2004; Goodhart, Hofmann \& Segoviano 2004; Illing \& Paulin 2005; Altman et al. 2005). It is clear that regulatory capital under Basel II would increase during recessions and decrease during periods of strong economic growth. This view holds for each of the different methods for setting ratings even though, as Altman and Saunders (2001) argue, changes in corporate security ratings (by the major ratings agencies) tend to lag the changes in credit conditions.

The pro-cyclical criticism assumes that bank capital is varied according to movements in the minimum capital requirement. Banks in Australia have consistently held capital well above their required minimum and thus have always held a capital buffer. Consequently, proposals for Basel II's capital requirement to be set as an average risk across the cycle (Goodhart, Hofmann \& Segoviano 2004: 599) and that regulators embed a counter-cyclical capital buffer in Pillar 2 during periods of economic growth that could be drawn upon during an economic downturn may not seriously distort banks' actual capital levels. Implementation of the latter proposal, though, would need to harmonise with 
monetary policy and so require close cooperation (in Australia) between APRA and the RBA.

While actual capital ratios may be less pro-cyclical than regulatory capital, there is a good case for banks to hold a counter-cyclical capital buffer to improve their financial stability (that is, capacity to absorb lower earnings and even losses). Since the required return on equity falls as share prices increase (and vice versa), the capital buffer would be raised when the cost of equity capital is lower than if banks had to increase their capital when their share prices are depressed.

\section{Market Discipline}

The effectiveness of disclosure requirements and market discipline is the subject of a lengthy literature.

Bliss \& Flannery (2001: 108-9) draw an important distinction between the roles of monitoring and influence in assessing the potential effectiveness for market discipline to enhance bank regulation. Information which is monitored, correctly understood and acted upon by investors, so that it leads to changes in the market prices of debt and equity, will result in effective bank discipline only if management responds to the changed market prices with modified risk-taking behaviour. They further point out monitoring behaviour has two pre-conditions. The first is that participants must have an incentive to monitor. Depositors covered by a perceived safety net are unlikely to have this incentive, while equity holders and holders of debt which ranks below deposits are more likely to have an incentive to monitor. The second is that the suppliers of funds must have the ability to accurately interpret disclosed information. The common answer is that most depositors are unlikely to have this ability while a greater proportion of equity and subordinated debt holders could be expected to have it, especially when they are institutional investors.

Flannery (1998) surveyed the evidence of monitoring and found that investors respond to and correctly interpret changes in bank conditions, that there is little evidence of irrational contagion and that on-site regulatory inspections contribute at least some information that markets use to discipline banks. Esho, Kofman, Kollo \& Sharpe (2005) provide similar evidence that accounting risk measures for Australian banks are accurately reflected in the risk spread on bank subordinated debt over the return on Australian Government securities. However, Bliss \& Flannery (2001: 141) found little evidence to support the influence dimension of market discipline and argued that it would be dangerous for regulators to rely on a market discipline mechanism in the absence of evidence that supports its existence. For this reason, commentators such as Gup (2004b: 82-4 and 86-8) and Kaufman (2004: 46) argue that Basel II's Pillar 3 provisions are likely to contribute little to effective bank supervision. 
Calomiris \& Powell (2001), however, suggest an alternative channel by which market discipline might enhance prudential supervision. They argue that the monitoring effect may impose discipline not on bank managers but on regulatory authorities, overcoming a problem of regulatory forbearance identified by Boot $\&$ Thakor (1993). They argue that regulators may delay taking corrective action when banks become financially distressed because of the high cost to taxpayers of closing a troubled institution and, instead, rely on the hope of bank recovery. The forbearance of APRA toward HIH in late 2000 and early 2001 prior to its $\$ 5$ bn insolvency appears to be a case in point. The regulator delayed conducting a formal investigation into $\mathrm{HIH}^{\prime}$ s financial situation that should have been triggered by its failure to submit its quarterly financial statement for December 2000. The HIH case, though, illustrates that the regulator was not influenced by the market's discipline since HIH's share price fell sharply (from \$1 to \$0.20) in late 2000. Presumably APRA will not repeat this mistake and so the introduction of Pillar 3 should mean that the regulator will be influenced by market signals and so place pressure on ADI management to do likewise.

\section{Impact on small-business lending}

Under Basel II loans to small and medium-sized businesses (SMEs) can be treated as either retail loans or corporate loans. The former are pools of standardised smaller loans whereas the latter are customised larger loans. Under Basel II retail loans attract a lower capital charge (6 per cent); one reason for which is the view that such loans are less sensitive to systemic risk than corporate loans (Jacobson, Lindé and Roszbach 2005: 44). This view has attracted some debate but, irrespective of its validity, Altman and Sabato (2005) argue that (particularly in the US banking system) larger banks are more likely to be able to benefit from the lower charge. Berger (2006), though, concludes otherwise, arguing that the SME loan market is segmented and larger banks are unlikely to enter the segment dominated by smaller banks. Given the dominant role of Australia's large banks in the SME loan market it seems unlikely that the treatment of retail loans under Basel II will have much influence on small-business lending or on which banks dominate this segment of bank lending.

\section{Basel II and competitive neutrality}

Under Basel II credit and operating risk weights determined under the standard approach are likely to be higher than under the internal ratings approaches (McDonald \& Eastwood 2000; Egan 2004: 4; Egan 2007; BCBS 2003: 4). This raised the concern that the smaller ADIs (the regionals, credit unions and building societies) would be placed at a competitive disadvantage to the larger banks by the different methods for calculating risk factors. Egan (2004: 7) disputed that requiring smaller banks to hold larger amounts of capital represents a distortion of competitive neutrality. Egan argued that small ADIs are inherently riskier 
than larger banks since they have less-diversified loan portfolios and so face greater risk.

A related concern is the impact that Basel II might have on concentration in the banking industry. Given that the internal-ratings approaches under Basel II imply a lower regulatory capital requirement (than the standard approach) they represent an economy of scale that would encourage consolidation between banks. The merits of this potential impact would depend on the form of consolidation and whether the outcomes are anti-competitive. Mergers between regionals (such as between Bendigo and Adelaide banks) would be less likely to be anti-competitive than mergers with a big bank (such as between Westpac and St George and between the Commonwealth and BankWest). Where mergers enable the new organisation to adopt superior risk-measurement techniques this would be in the public interest. But fewer bigger banks intensifies the 'too big to fail' dilemma for APRA and ultimately for the community (through the cost of bail-outs, should they occur). A more concentrated banking industry may also increase contagion risk within the wholesale payment system.

\section{Basel II and the global financial crisis}

The GFC began to take hold in 2007. Its origins can be traced to a boom in US housing prices between 2002 and 2005 and the rapid growth of sub-prime housing loans following a doubling of the amount of prime loans between 2001 and 2003. Consequently, the crisis largely preceded the introduction of Basel II, which in Australia was at the start of 2008 whereas in the USA it was introduced over 2008 in parallel with the current requirements and applied only to the large internationally-active banks.

Sub-prime loans are those made to borrowers with a weak capacity to make their loan payments (compared with prime loans) and thus an increase in such lending represents a decline in lending standards. Sub-prime loans though were encouraged in the US as a way of democratising lending by providing loans to those who were not eligible for prime loans, including minorities. The loans' business model, though, was flawed because it depended on continuously rising prices for the mortgaged properties. The assumed capital gain served to compensate the lender for losses from loan delinquencies or encouraged delinquent borrowers to refinance with the lender at a higher interest rate.

The growth in lending for housing promoted an increase in the supply of housing that resulted in the stock of housing exceeding the demand. This led to a fall in housing prices that was exacerbated by the high (and rising) rate of mortgagee sales from the sub-prime loans. The crisis quickly spread to the securities markets because most of the sub-prime loans were securitised through asset-backed commercial paper (short-term securities that provided initial finance for the loans) and MBSs (long-term bonds that ultimately funded the loans). The 
value of the highest-rated (AAA) of these securities (surprisingly, most MBSs based on sub-prime loans were rated AAA) halved between July 2007 and March 2008, which created a major credit crisis for two reasons. First, new issuers could not borrow because they could not afford the resulting higher interest rate and, second, investors only wanted to sell the securities; and so liquidity in both the primary and secondary markets for MBSs dried up.

The crisis spread to the related markets for structured securities such as collateralised-debt obligations (the collateral for which was sub-prime loans) and for credit-default swaps, drying up liquidity in these markets. A related feature of the credit crisis was the retreat by investors to US Treasury and other 'safe' bonds, driving down their yields and further widening the credit spreads between them and those for structured and similar securities. The crisis spread to the large US investment banks (they were not subject to prudential supervision) as well as commercial banks when it became clear that they held large amounts of these ('toxic') securities on their balance sheets and this contracted the flow of funds by banks (and even more disturbingly) between banks. The global nature of the affected financial markets and a surprising lack of information about banks' exposures (which spread fear) meant the credit crisis quickly became global in scope.

The BCBS, along with other pan-national agencies (Knight 2008), has analysed the causes of the threat the GFC poses for global financial stability and the Committee announced (in March 2008) it was developing four amendments to Basel II in response:

1. In relation to Pillar 1 it was examining the adequacy of the capital charge for structured securities given their highly correlated risk exposure (being backed by assets of the same type) which led to their sudden downgrading. The value-at-risk method of assessing the capital requirement for such securities during periods of low volatility did not adequately reflect their credit risk when volatility suddenly increased. Concern had been expressed when Basel II was being developed about the shortcomings of value-at-risk models in the context of financial system instability. (Goodhart, Hofmann and Segoviano 2004: 598)

2. The Committee was also developing a credit-default risk charge on assets held in banks' trading books. This is in recognition of the credit risk posed by structured credit products that do not have a liquid secondary market.

3. In relation to Pillar 2 the BCBS is proposing that regulators widen their stress tests of banks' risk-management systems to include contingent credit exposures such as those that arose when banks took back securitised (or collateralised) assets for reputation reasons. 
4. The BCBS is also reviewing its disclosure requirements (under Pillar 3) in relation 'to securitisations, conduits and the sponsorship of off-balance sheet vehicles' (Wellink 2008; BCBS 2008b).

Prior to the crisis the BCBS had began a review of liquidity-risk management and supervision, but given that market and funding illiquidity are core aspects of the credit crisis, the work was given greater priority. The intention is to strengthen its standards for liquidity-risk management and supervision, especially in relation to liquidity stress testing that includes off-balance sheet exposures and for funding capacity during periods of wholesale market funding illiquidity; as well as its reporting and disclosure standards relating to liquidity (BCBS 2008a). APRA has responded by intensifying its monitoring of bank liquidity and by strengthening its liquidity-management requirements on banks.

The GFC provides a real-life stress test of the stability of the financial system and the regulatory framework that is intended to promote the financial system's stability. Basel II forms a fundamental part of the prudential supervision of individual banks that serves to strengthen their individual stability through their capital buffer; but it does not aim to ensure financial system stability. Consequently, despite its recognised flaws, which the BCBS has moved to remedy, Basel II did not contribute to the emergence of the GFC. As noted above, the origins of the crisis pre-dated the introduction of Basel II in the USA. The same cannot be said about the anti-regulation political culture in the USA.

In the USA, sub-prime lenders included non-depository 'mono-line' lenders (referred to in Australia as 'loan originators') and large banks, as well as community banks, consumer finance companies and thrifts, many of whom along with investment banks arranged the issue of MBSs (Ashcraft and Schuermann 2008). As noted above, Basel II has been applied in the US only to their internationally active commercial banks. The widespread use of originate-to-distribute lending in the US has been referred to as a 'shadow banking system' that increasingly relied on a flawed originate-to-distribute model (Ashcraft and Schuermann 2008 detail the various flaws), which in the case of sub-prime loans was based on a business model that itself was seriously flawed (because of its reliance on ever-increasing housing values and its incentives for predatory lending and borrowing). It should be recalled that the process of securitisation that enabled the originate-to-distribute lending model was an acclaimed financial innovation that accessed investors' funds for housing loans and so placed competitive pressure on bank lending.

The question for the prudentially-regulated banks that decided to undertake either sub-prime lending or underwrite the issue of MBSs (or otherwise establish an exposure to structured securities) is why their capital requirement (their capital ratios exceeded those of Basel I) did not motivate them to act more prudently. The answer appears to be that the motivation provided by their 
capital requirement to act prudently was outweighed by the pressure posed by competing institutions that were making profits from their appetite for risk taking; greed outweighed fear. The related question is: why did their prudential regulator tolerate their risk exposures? There is now a growing literature criticising the forbearance of financial and prudential supervision in the United States (Kane 2008; and Ashcraft and Schuermann, 2008). The role of ratings agencies and their supervision has also been criticised given the conflict of interest faced by the ratings agencies in assigning their AAA rating to securities based on sub-prime loans.

Fortunately, this debacle was not replicated in Australia. Sub-prime lending was largely confined to three smaller loan originators (Pepper, Bluestone and Liberty Financial) and Australia's banking system had very little exposure to the toxic securities (Debelle 2008: 43). Consequently the banks were not under competitive pressure to enter this segment of the loan market. The initial impact in Australia was in the inter-bank market, where the Australian banks became reluctant to lend to each other, preferring instead to increase their balances held with the RBA.

The main impact in Australia has been via the higher credit spreads in overseas financial markets, which had a relatively greater impact on non-bank lenders (the loan originators) because domestic and overseas MBSs markets had been their funding source. Deprived of funds, these lenders switched into mortgage brokerage, leaving the banks with an even larger share of the housing-loan market. The Government's guarantee of ADI liabilities has further strengthened the position of the large banks within the Australian financial system (RBA 2008b: 21-36).

APRA's review of credit standards for housing loans in 2006 (as well as the RBA's efforts to contain Australia's housing prices in 2002 and 2003) represented a stricter regulatory environment than occurred in the US. APRA's Chairman concluded a speech made in June 2007 with the following observations:

In repeating our concerns about credit standards, I am conscious that APRA might be perceived to be 'crying wolf' too often on housing lending. No one would welcome a continuation of Australia's economic strength and the recent resilience of most housing markets - from which ADIs have been major beneficiaries - more than the prudential regulator. Nonetheless, the risk currents in housing lending have been moving, slowly but inexorably, in one direction only and this demands careful management by our regulated lenders, and constant vigilance on APRA's part. (Laker 2007)

The comparison between the US and Australia's experience is instructive. Supervised banks in both systems employed similar levels of capital but many of the large US banks behaved less prudently than the large Australian banks 
and the Australian financial regulators displayed much more vigilance than the US regulators.

\section{Conclusions}

Basel II represents a substantial improvement on Basel I because of its more extensive integration of the capital requirement within the prudential supervision framework through its greater risk-sensitivity and comprehensive coverage of banking risks. Shortcomings (particularly in the modelling of credit risk) revealed by the GFC are being addressed, which should ultimately strengthen Basel II.

Of the concerns debated during the development of Basel II the main outstanding issue is its pro-cyclical effect. It is unlikely to be evident during the current economic crisis because of the greater effects of the GFC; illiquidity of markets and the tightening of lending standards by banks. But Basel II should be modified to counter its pro-cyclical effect.

The main lesson of the GFC for Basel II is that bank capital is a necessary but not sufficient requirement for a bank's stability. Prudential regulators need to be vigilant because the intended influence of the capital requirement on banks' risk-taking behaviour can be outweighed when competing institutions profit from their greater risk appetite, especially when there is a too-ready acceptance of financial innovation.

\section{References}

Altman, E. and Saunders, A. 2001, 'An Analysis and Critique of the BIS Proposal on Capital Adequacy and Ratings', Journal of Banking and Finance 25(1): 25-46.

Altman, E. I., Bharath, S. T. \& Saunders, A. 2002, 'Capital Ratings and the BIS Capital Adequacy Reform Agenda', Journal of Banking and Finance 26: 909-21.

Altman, E. and Sabato, G. 2005, 'Effects of the New Basel Capital Accord on bank Capital Requirements for SMEs', Journal of Financial Services Research 28: 1/2/3, 15-42

Altman, E., Brady, B., Resti, A. and Sironi, A. 2005, 'The Link between Default and Recovery Rates: Theory, Empirical Evidence and Implications', Journal of Business 78(6): 2203-27.

Ashcraft, Adam B. and Schuermann, Til 2008, 'Understanding the Securitization of Subprime Mortgage Credit', Federal Reserve Bank of New York Staff Reports: 318

Australian Prudential Regulation Authority 2004, 'The Basel II Capital Framework in Australia', APRA Insight, $4^{\text {th }}$ Quarter 2004: 13-18. 
Australian Prudential Regulation Authority 2007, Implementation of the Basel II Capital Framework; Market disclosure, Discussion Paper, June.

Australian Prudential Regulation Authority 2008, Prudential Standard APS 110 Capital Adequacy, January.

Australian Prudential Regulation Authority 2008, Prudential Standard APS 112 Capital Adequacy: Standardised Approach to Credit Risk, January.

Australian Prudential Regulation Authority 2008, Prudential Practice Guide APG 112 - Standardised Approach to Credit Risk, January.

Australian Prudential Regulation Authority 2008, Prudential Standard APS 115: Capital Adequacy: Advanced Approaches to Operational Risk, January.

Basel Committee on Banking Supervision 2003, Consultative Document: Overview of the New Basel Capital Accord, April, Basel: Bank for International Settlements.

Basel Committee on Banking Supervision 2004a, 'Bank Failures in Mature Economies', Basel Committee on Banking Supervision Working Paper Series, No. 13, April.

Basel Committee on Banking Supervision 2004b, International Convergence of Capital Measurement and Capital Standards: A Revised Framework, June, Basel: Bank for International Settlements.

Basel Committee on Banking Supervision 2008a, Liquidity Risk: Management and Supervisory Challenges, February.

Basel Committee on Banking Supervision 2008b, Basel Committee on Banking Supervision announces steps to strength the resilience of the banking committee, April, www.bis.org/

Berger, A. 2006, 'Potential Competitive Effects of Basel II on Banks in SME Credit markets in the United States', Journal of Financial Services Research 29(1): $5-36$

Bliss, R. R. \& Flannery, M. J. 2001, 'Market Discipline in the Governance of U.S. Bank Holding Companies: Monitoring versus Influencing', Mishkin F. S. (ed.), Prudential Supervision: What Works and What Doesn't, Chicago: Chicago University Press: 107-43.

Boot, A. \& Thakor, A. V. 1993, 'Self-Interested Bank Regulation', American Economic Review 83: 206-12.

Calomiris, C. W. \& Powell, A. 2001, 'Can Emerging Market Bank Regulators Establish Credible Discipline? The Case of Argentina 1992-99', in Mishkin F. S. (ed.), Prudential Supervision: What Works and What Doesn't, Chicago: Chicago University Press: 146-90. 
Debelle, G. 2008, 'A Comparison of the US and Australian Housing Markets', RBA Bulletin (June): 35-46.

Egan, B. 2004, 'APRA Update: Basel II Implementation in Australia', The Australian Financial Review's $5^{\text {th }}$ Annual BankTech Conference, 14 September.

Egan, B. 2007, 'Meeting the Challenges of the Implementation of Basel II', apra.gov.au/speeches

Esho, N., Kofman, P., Kollo, M. G. \& Sharpe, I. G. 2005, 'Market Discipline \& Subordinated Debt of Australian Banks', Australian Prudential Regulation Authority Working Paper Series, October.

Flannery, M. J. 1998, 'Using Market Information in Prudential Bank Supervision: A Review of the U.S. Empirical Evidence', Journal of Money Credit and Banking 30(3): 273-305.

Gizycki, M. \& Lowe, P. 2000, 'The Australian Financial System in the 1990s', Gruen, D. \& Shrestha, S. (eds), Sydney: Reserve Bank of Australia: $180-215$.

Goodhart, C. A. E., Hofmann, B. \& Segoviano, M. 2004, 'Bank Regulation and Macroeconomic Fluctuations', Oxford Review of Economic Policy 20(4): 591-615.

Gup, B. 2003, 'A Brief History of Basel', Journal of Banking and Financial Services 117(5): 74-5.

Gup, B. 2004a, 'The New Basel Accord: Is 8\% Adequate?' in Gup, B. (ed.), The New Basel Capital Accord, New York, Thomson: 11-28.

Gup, B. 2004b, 'Market Discipline: Is It Fact or Fiction?' in Gup, B. (ed.), The New Basel Capital Accord, New York, Thomson: 67-96.

Hogan, W. \& Sharpe, I. G. 1997a, 'Prudential Regulation of the Financial System: A Functional Approach', Agenda 4: 15-28.

Hogan, W. \& Sharpe, I. G. 1997b, 'Financial System Reform: Regulatory Structure, Financial Safety, Systemic Stability and Competition Policy', The Economic and Labour Relations Review: 318-32.

Illing, M. \& Paulin, G. 2005, 'Basel II and the Cyclicality of Bank Capital', Canadian Public Policy 31(2): 161-80.

Jacobson, T., Lindé, J. and Roszbach, K. 2005, 'Credit Risk Versus Capital Requirements under Basel II: Are SME Loans and Retail credit Really Different?', Journal of Financial Services Research 28:1/2/3, 43-75.

Kane, Edward J. 2008, 'Ethical failures in Regulating and Supervising the Pursuit of Safety Net Subsidies', available at: http://ssrn.com/abstract $=12735616$ 
Kashyap, A. K. \& Stein, J. C. 2004, 'Cyclical Implications of the Basel II Capital Standards', Federal Reserve Bank of Chicago Economic Perspectives, $1^{\text {st }}$ Quarter: 18-31.

Kaufman, G. G. 2004, 'Basel II: The Roar that Moused', in Gup, B. (ed.), The New Basel Capital Accord, New York, Thomson: 39-52.

Knight, M. D. 2008, 'Weaknesses revealed by the market turmoil: where do we go from here?' bis.org/speeches

Laker, John 2007, 'Credit Standards in Housing Lending — some further insights', apra.gov.au/speeches

McDonald, A. \& Eastwood, G. 2000, 'Credit Risk Rating at Australian Banks', Australian Prudential Regulation Authority Working Paper No.7, December.

Reserve Bank of Australia 1988, Capital Adequacy of Banks, Prudential Statement No. Cl, Sydney.

Reserve Bank of Australia 1989, 'The New Capital Adequacy Guidelines for Australian Banks', Reserve Bank of Australia Bulletin, January: 6-12.

Reserve Bank of Australia 2006, Financial Stability Review, September: 46-9.

Reserve Bank of Australia 2008a, Financial Stability Review, March.

Reserve Bank of Australia 2008b, Financial Stability Review, September.

Resti, A. 2002, The new Basel capital accord; Structure, possible changes, microand macroeconomic effects, Brussels: Centre for European Policy Studies.

Wellink, Nout 2008, 'Basel II — market developments and financial institution resiliency', Speech at Basel II Implementation Summit, Singapore, March 2008. 